\title{
Phellodon secretus (Basidiomycota), a new hydnaceous fungus from northern pine woodlands
}

\author{
TUOMO NIEMELÄ, JUHA KINNUNEN, PERTTI RENVALL and DMITRY SCHIGEL
}

\begin{abstract}
NIEMELÄ, T., KINNUNEN, J., RENVALL, P. \& SCHIGEL, D. 2003: Phellodon secretus (Basidiomycota), a new hydnaceous fungus from northern pine woodlands.Karstenia 43: 37-44. 2003.

Phellodon secretus Niemelä \& Kinnunen (Basidiomycota, Thelephorales) resembles Phellodon connatus (Schultz : Fr.) P. Karst., but differs in having a thinner stipe, cottony soft pileus, and smaller and more globose spores. Its ecology is peculiar: it is found in dry, old-growth pine woodlands, growing in sheltered places under strongly decayed trunks or rootstocks of pine trees, where there is a gap of only a few centimeters between soil and wood. Basidiocarps emerge from humus as needle-like, ca. $1 \mathrm{~mm}$ thick, black stipes, and the pileus unfolds only after the stipe tip has contacted the overhanging wood. In its ecology and distribution the species resembles Hydnellum gracilipes (P. Karst.) P. Karst. It seems to be extremely rare, found in Northern boreal and Middle boreal vegetation zones, in areas with fairly continental climate.
\end{abstract}

Key words: Aphyllophorales, Phellodon, hydnaceous fungi, taxonomy

Tuomo Niemelä, Juha Kinnunen \& Dmitry Schigel, Finnish Museum of Natural History, Botanical Museum, P.O. Box 7, FIN-00014 University of Helsinki, Finland

Pertti Renvall, Kuopio Natural History Museum, Myhkyrinkatu 22, FIN-70100 Kuopio, Finland

\section{Introduction}

Virgin pine woodlands of northern Europe make a specific environment for fungi. The barren sandy soil, spaced stand of trees and scanty lower vegetation result in severe drought during sunny summer months, in particular because such woodlands are usually situated on exposed hillsides, river banks, and tops of eskers. Pinus sylvestris grows in almost pure stands, accompanied by single Picea abies and Betula pubescens here and there. Slowly growing and straight pine trees give excellent timber, and nowadays fairly little is left intact of these handsome forests.

Fungal decomposition proceeds slowly in such dry habitats, and just a few wood-rotting species can easily occupy dry coarse woody debris there. In natural conditions pine trees die of wildfires or fall down in storms, but quite a lot of them succeed to reach a high age of 300-500(-800) years, eventually dying while standing. Such dead pine trees may keep standing for another 200-500 years, losing their bark and thinner branches: in this way the so-called kelo trees develop, common and characteristic for northern old-growth pine woodlands. This process was described in detail by Niemelä et al. (2002), and in that paper many wood-inhabiting fungi of the kelo trees were listed.

A team of mycologists from the University of Helsinki (Yu-Cheng Dai, Juha Kinnunen, Olli Manninen, Tuomo Niemelä, Dmitry Schigel, Olli Turunen) has inventoried protected old forests of North and East Finland during the years 19982002. These studies were initiated and organized by the local offices of the governmental Natural Heritage Services; for the background of the inventories in Lapland, see Niemelä et al. (2003). 
This intensive and laborious fieldwork revealed a number of previously unknown fungal species, among them the peculiar hydnaceous fungus described here.

During the preparation of this paper it turned out that Pertti Renvall had collected the same species already in the 1980s in eastern Lapland.

\section{Materials and methods}

Specimens of the new species were collected by the authors with coworkers. They were photographed in the field, and fresh character and ecology notes were made. Specimens were dried soon after field trips in mushroom dryer with ventilated $30-40^{\circ} \mathrm{C}$ temperature.

In addition to the new species, selected voucher materials of related Phellodon species were studied for comparison. All the specimens listed are deposited in the Botanical Museum of the University of Helsinki (H), unless otherwise indicated. Herbarium abbreviations are according to Holmgren et al. (1990).

Microscopic studies were done and spores were measured from sections mounted in Cotton Blue (abbreviated $\mathrm{CB}$ ): $0.1 \mathrm{mg}$ aniline blue (Merck 1275) dissolved in $60 \mathrm{~g}$ pure lactic acid; $\mathrm{CB}+$ means cyanophily, $\mathrm{CB}(+)$ weak but distinct cyanophilous reaction, $\mathrm{CB}-$ acyanophily. Amyloid and dextrinoid reactions were tested in Melzer's reagent (IKI): $1.5 \mathrm{~g} \mathrm{KI}$ (potassium iodide), $0.5 \mathrm{~g} \mathrm{I}$ (crystalline iodine), $22 \mathrm{~g}$ chloral hydrate, aq. dest. $20 \mathrm{ml}$; IKImeans neither amyloid nor dextrinoid reaction. Occasionally also $5 \% \mathrm{KOH}$ was used as mountant or reagent.

As a rule 30 spores were measured from each specimen selected for closer scrutiny; spore spines were excluded while measuring the dimensions. Measurements were done using $\times 1250$ magnification, phase contrast, oil immersion; eyepiece scale bar showed a $1-\mu \mathrm{m}$-grid, and dimensions were estimated visually with an accuracy of $0.1 \mu \mathrm{m}$. In presenting the variation of spore size, $5 \%$ of the measurements out of each end of the range are given in parentheses. $\mathrm{L}=$ mean length (arithmetical mean of all spores), $\mathrm{W}=$ mean width, $\mathrm{Q}=$ extreme values of the length/width ratios among the studied specimens, and $n=$ the number of spores measured from given number of specimens.

SEM photographs were taken by Cambridge Scan S-2 microscope (20 Kv, registration of secondary electrons). Preliminary picture editing was made in MicroCapture 2.2. and further editing in Corel PhotoPaint 9.

The main reference books used were: Coker \& Beers (1951), Nikolaeva (1961), Maas Geesteranus (1971, 1975), Domański (1975), Baird (1986a, b), Breitenbach \& Kränzlin (1986), Stalpers (1993), and Hansen \& Knudsen (1997). Special colour terms are from Anonymous (1969), Rayner (1970) and Petersen (1996).

\section{Phellodon secretus Niemelä \& Kinnunen, species nova}

-Figs. 1-4

Fungus stipitatus, aculeatus, terrestris, parvus. Pileus mollis, tomentosus, griseoalbus, azonatus, stipite tenui, spiculoso, nigro, aculeis al- bidis vel griseoalbis. Hyphae hyalinae, afibulatae; sporae hyalinae, globosae, spiculatae, 2.9$3.3 \times 2.7-3 \mu \mathrm{m}$.

Typus: Finland, Pohjois-Karjala Prov., Ilomantsi, Koivusuo, 26.IX.2002 Niemelä 7460, Kinnunen \& Schigel (holotype, H).

Etymology: secretus (Latin, adj.) = separate, hidden, set aside, secret, etc., referring to the way of growth out of sight under fallen trunks.

Basidiocarp terrestrial, stipitate, small, slender and fragile, single or confluent with 2 or more, separate stipes supporting a common pileus. Pileus plane or funnel-shaped or irregularly roundish and lobed, $0.9-3(-5.5) \mathrm{cm}$ in diam., very thin, $0.3-1.5(-3.5) \mathrm{mm}$, cottony soft throughout, at first white with ash-grey tint, later darker grey (mousegrey) or with a hue of sepia, evenly coloured (young) or paler towards the margin (old), but not zonate. Lower surface at first white, then light greyish white (pale mouse-grey), spines sharp, slender, regular, dense, finally $0.3-0.9(-1.5) \mathrm{mm}$ long and $0.06-0.12 \mathrm{~mm}$ diam. at base. Stipe black, glabrous, very thin, $0.3-1.8(-2.3) \mathrm{mm}$ and of even thickness, $10-18 \mathrm{~mm}$ long, brittle when dry. A slice of context stains olivaceous (pale brownish green) in $\mathrm{KOH}$. Fresh basidiocarp odourless, dry with very faint spicy scent.

Monomitic, hyphae simple-septate, hyphal walls $\mathrm{CB}+$, IKI-, mostly $\mathrm{KOH}-$; hyphae of context and stipe covered with minute, scattered, amyloid granules. Context hyphae thin-walled, of even thickness (not inflated), hyaline except close to lower surface where slightly grey-brown, (2.8-) $3-4.2(-4.7) \mu m$ in diam. $(n=30 / 1)$, making a spaced interwoven network where a few hyphae often run parallel in bundles; context hyphae olivaceous in KOH. Stipe surface with parallel, slightly thickwalled, black-brown hyphae with prominent septa, (3.2-)3.6-5(-5.7) $\mu \mathrm{m}$ in diam. $(n=30 / 1)$; of them long, single hyphal tips arise upwards, but no differentiated tomentum present; stipe medulla with brown, regular, subparallel hyphae, (2.7-)3.4$4.7(-5) \mu \mathrm{m}$ in diam. $(\mathrm{n}=30 / 1)$. Tramal hyphae in spines very thin-walled, fragile, of even thickness, subparallel, hyaline (pale brownish in inner parts close to attachment), (2.1-)2.6-3.5(-3.7) $\mu \mathrm{m}$ in diam. ( $\mathrm{n}=30 / 1)$; subhymenium not differentiated. Hymenium with basidia and basidioles only, basidia clavate with long, rooting base, $21-34 \times 4.9$ $5.6 \mu \mathrm{m}(\mathrm{n}=10 / 1)$, sterigmata 4 , no basal clamp; basidioles clavate, (16-)20-29 ×(3.8-)4.7-5 $\mu \mathrm{m}$ $(\mathrm{n}=10 / 1)$; hyphal tips regular at spine apex. 

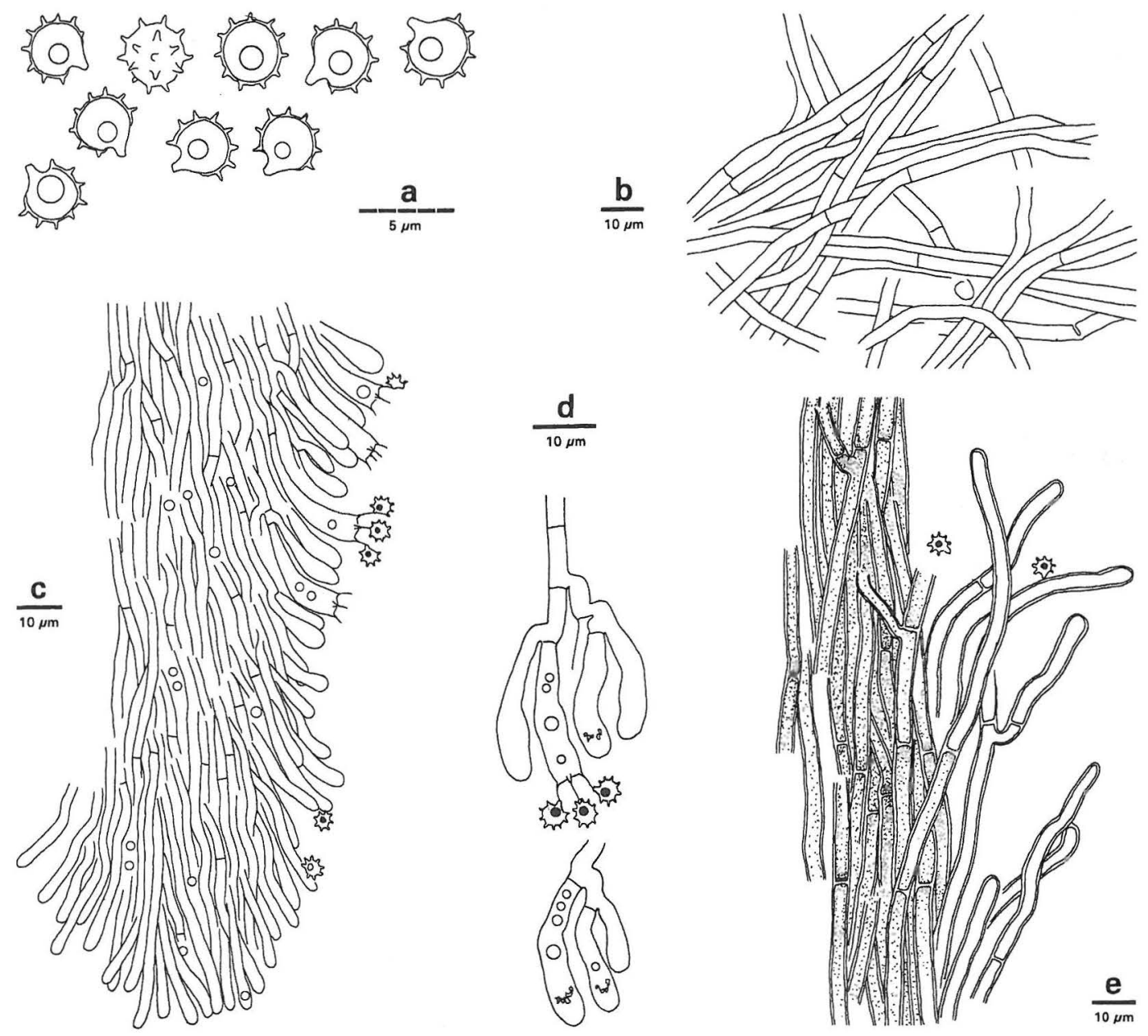

Fig. 1. Phellodon secretus Niemelä \& Kinnunen. a) spores, b) hyphae from context, c) vertical section of aculeus, d) hymenial cells, e) section from stipe surface. Drawn by TN in CB from holotype.

Basidiospores globose, thin-walled, hyaline, $\mathrm{CB}-$ or $\mathrm{CB}(+), \mathrm{IKI}-, \mathrm{KOH}-,(2.8-) 2.9-3.3(-3.8) \times$ (2.4-)2.7-3(-3.2) um, $\mathrm{L}=3.10 \mu \mathrm{m}, \mathrm{W}=2.87 \mu \mathrm{m}, \mathrm{Q}=$ $1.06-1.10(\mathrm{n}=180 / 6)$, with separate spines, distinct oblique apiculus, and medium to small guttule.
Specimens studied: Finland. Etelä-Häme Prov:: Tammela, Mustiala, Syrjäås, 21.VIII.1866 Karsten 4677; 6.X.1866 Karsten (F. Fenniae Exs. 10: 907, H; Herb. E. Fries, UPS). Pohjois-Karjala Prov.: Ilomantsi, Hattuvaara, Koivusuo Strict Nat. Res., 26.IX.2002 Niemelä 7460, Kinnunen \& Schigel; 


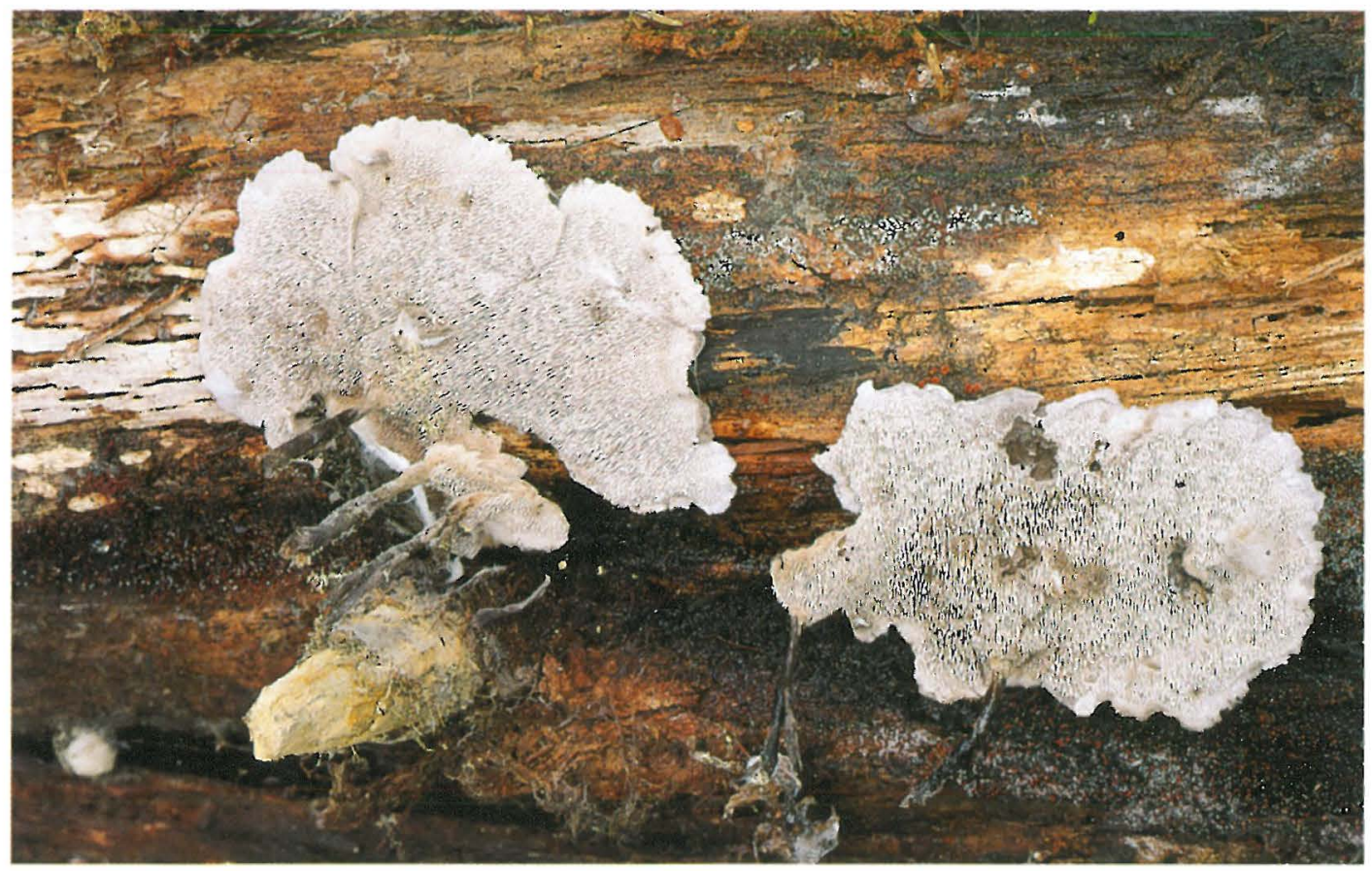

Fig. 2. Phellodon secretus Niemelä \& Kinnunen, basidiocarps in situ. Holotype, approximately natural size, photo TN.

29.IX.2002 Kinnunen 1727, Niemelä \& Schigel. Kittilän Lappi Prov.: Kolari, Ylläsjärvi, Tunturipalo, 9.IX.1999 Niemelä 6646, 6648 \& Renvall 3873 (KUO). Muonio, Äkäskero, 22.VIII.1999 Niemelä 6508, 6509 \& Dai. Sompion Lappi Prov: Savukoski, Urho Kekkonen Nat. Park, Jaurujoki, Peuraselkä, 23.IX.1987 Renvall 628.

\section{Ecology and distribution}

The new species is very special in its ecology. All fruit bodies found by us were growing in virgin, dry pine woodlands, in narrow spaces under fallen pine trees. The wood was either extensively rotten trunk, or rootstock of long-ago fallen tree, preferrably kelo (Niemelä et al. 2002). Such sheltered places were dry even in rainy days. The reason of favouring such places may be that there is less competition between mycelia there, or that even though the site is dry, its humidity is very constant throughout the season, because of little ventilation in the narrow gap.

We got an impression that the new species is mycorrhizal, because basidiocarps clearly arose from the humus. According to Urmas Kõljalg (pers. comm.), 'so far it is known that all the tested species of the Thelephorales, including the resupinate genera Pseudotomentella, Tomentel$l a$ and Tomentellopsis, are mycorrhizal. Therefore it is logical to deduce that $P$. secretus is mycorrhizal, too.'

Basidiocarps start to develop as black, needle-thin stipes, sharp at their apex. In some cases tens of such erect stipes were emerging side-byside on humus or sandy soil. The pileus usually starts to grow only after the tip touches the overhanging wood, and if the distance is too long, the growth may terminate and only needle-like stipes are left (e.g., specimen 6509). The growing pileus spreads along the wood surface above, and becomes lightly attached to it so that when the wood is lifted up, the stipe sometimes breaks apart and pileus follows the wood, or the pileus becomes detached and whole basidiocarp remains standing on the ground beneath.

Our finds imply that the new species is at least nowadays a rarity of northern pine forests. However, two collections by P.A. Karsten from the 
year 1866 (in H and UPS) derive from southern Central Finland. It seems that Karsten hesitated to name his material (evidently recollected from a single site), because he sent the second collection to Fries; no new name was proposed by either Karsten or Fries. The collecting site at Ilomantsi belongs to slightly continental section of Middle boreal zone (Ahti et al. 1968). Most collections were made in Finnish Lapland (Northern boreal zone): in easternmost parts (Savukoski, Renvall 628) and communes of Kolari and Muonio in the west, in forests belonging to the planned, extensive Ylläs-Pallas National Park (Koivisto 2003), extending in north-south direction throughout western Finnish Lapland. We have not seen material from other countries.

\section{Related species}

In its size, the very thin stipe and the peculiar way of growth Phellodon secretus resembles Hydnellum gracilipes (P. Karst.) P. Karst., and in fact the two species were sometimes found growing in the same forest, under separate tree trunks but not far from each other. While the 'stipe' of $H$. gracilipes (see Kõljalg \& Renvall 2000) is just a fragile rhizomorph or mycelial cord, the present species has a true, differentiated stipe. The two species differ clearly in their colours, $H$. gracilipes being bright purple-brown.

The closest relative is Phellodon connatus (Schultz : Fr.) P. Karst. (=P. melaleucus (Fr. : Fr.) P. Karst.), also having a black, glabrous stipe. That species is usually more robust: both cap and stipe are thicker and tough both when fresh and dry. The spicy odour of dry P. secretus is faint, hardly noticeable, while it is strong and pungent in $P$. connatus. At least in Finland P. connatus usually grows in spruce-dominated forests amongst thick moss and fairly moist ground; also when found in pine forests the moss layer is thick in places where the fruit bodies of $P$. connatus emerge. In most cases macroscopy and ecology are enough to separate it from $P$. secretus, but every now and then dwarf basidiocarps are found. Then spore size and shape are the differentiating characters (Fig. 3, Tab. 1); context hyphae of $P$. connatus are more densely packed than in the new species, and almost parallel, thus offering another striking difference.

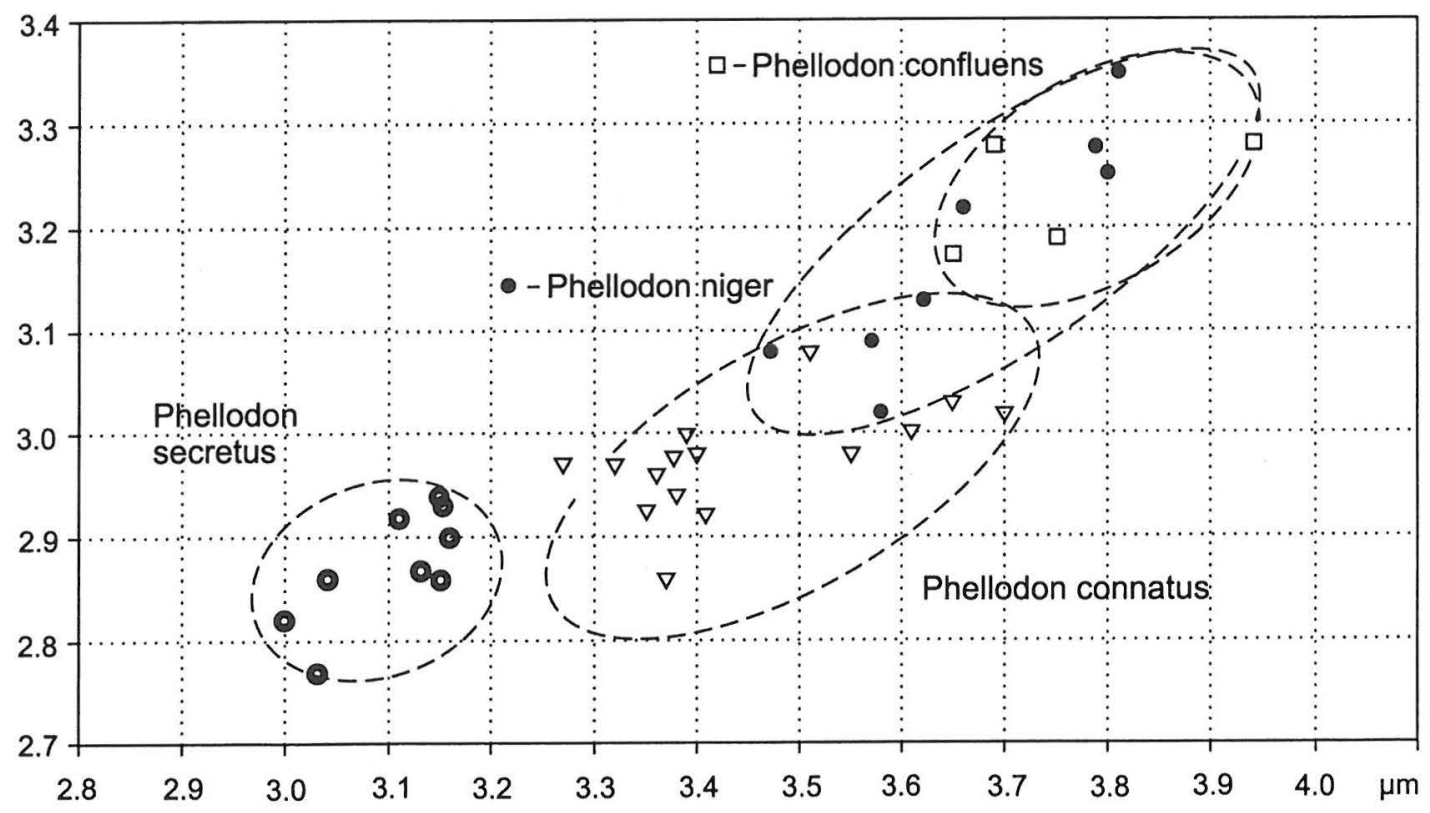

Fig. 3. Spore dimensions in four species of Phellodon. Spore spines were excluded from the measurements. Each symbol indicates a single specimen, mean value of 30 spores measured in $\mathrm{CB}$. 
Table 1. Spore dimensions of the specimens studied. 30 spores were measured for each specimen. Spore spines were excluded from the measurements.

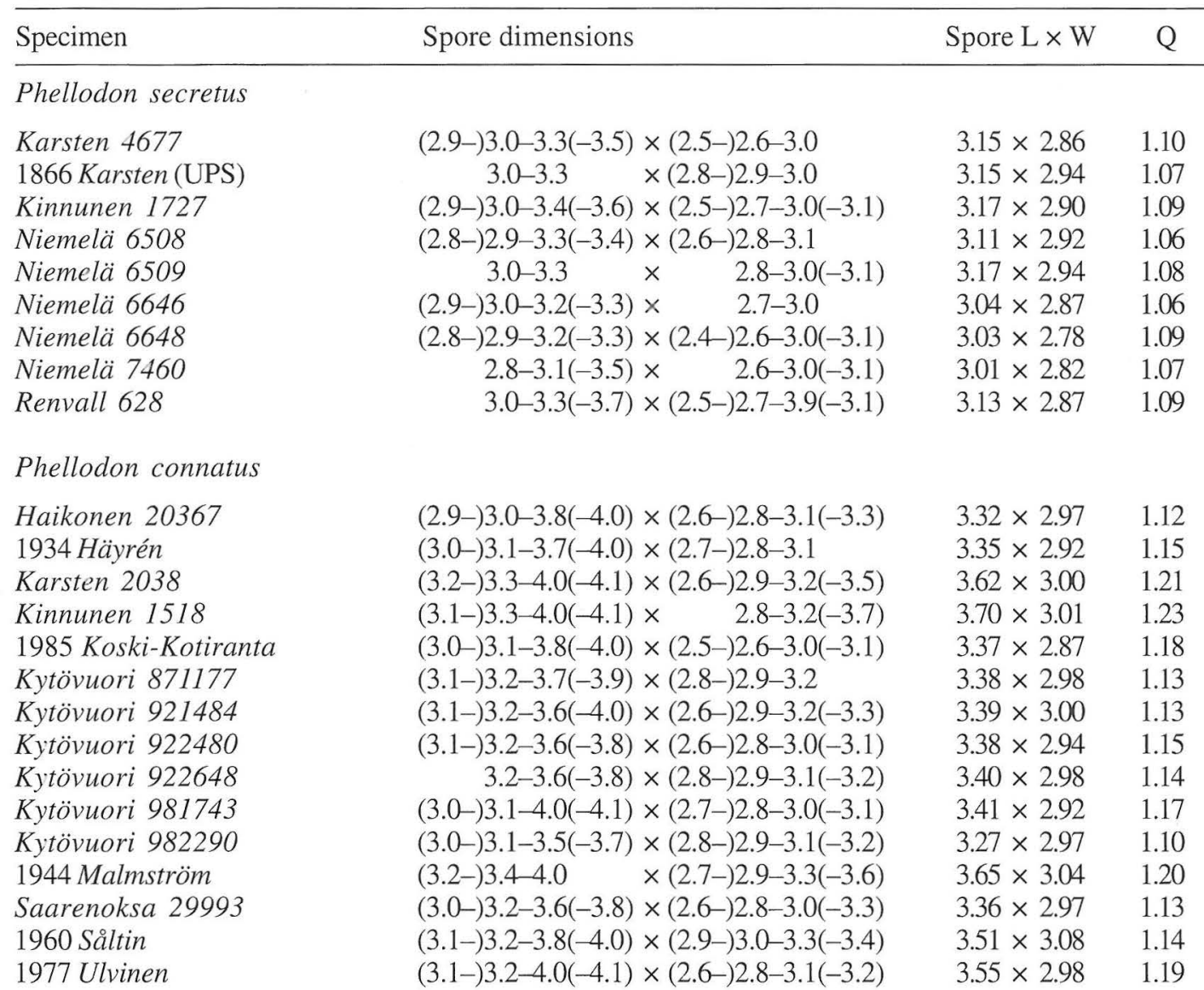

Phellodon niger

Askola 407

Askola 1811

Askola 2492

1943 Häyrén

Niemelä $5682 b$

Niemelä 1712

Niemelä 2310

1948 v. Schulmann

$\begin{array}{ll}(3.2-) 3.3-4.0(-4.1) & \times \quad 3.0-3.6(-3.7) \\ (3.1-) 3.4-4.0(-4.1) & \times(2.9-) 3.0-3.7(-3.9) \\ (3.1-) 3.2-4.0 & \times(2.8-) 3.0-3.3(-3.4) \\ (3.0-) 3.2-4.0(-4.2) & \times(2.7-) 2.9-3.1(-3.5) \\ 3.1-3.8(-4.0) & \times(2.8-) 2.9-3.2(-3.5) \\ (3.1-) 3.4-4.1(-4.3) & \times(3.0-) 3.1-3.7(-3.9) \\ (3.3-) 3.4-4.0 & \times(3.0-) 3.1-3.7(-3.8) \\ (3.0-) 3.2-4.0 & \times(2.9-) 3.0-3.3(-3.6)\end{array}$

$3.66 \times 3.21 \quad 1.14$

$3.80 \times 3.25 \quad 1.17$

$3.61 \times 3.13 \quad 1.15$

$3.58 \times 3.02 \quad 1.19$

$3.47 \times 3.08 \quad 1.12$

$3.79 \times 3.28 \quad 1.16$

$3.81 \times 3.35 \quad 1.14$

$3.57 \times 3.09 \quad 1.15$

Phellodon tomentosus

Kytövuori 901839

Kytövuori 902033

$(3.5-) 3.7-4.0(-4.2) \times(3.0-) 3.2-3.6(-3.7)$

$3.86 \times 3.38$

1.14

$3.9-4.3(-4.7) \times(3.4-) 3.5-3.9(-4.0) \quad 4.13 \times 3.74 \quad 1.10$

Korhonen 11230

$(3.6-) 3.8-4.2 \times(2.8-) 3.0-3.6(-3.7)$

$3.97 \times 3.26-1.22$

Phellodon alboniger

1961 Hintikka

$(4.0-) 4.2-4.8(-5.2) \times(3.2-) 3.6-4.0(-4.3)$

$4.45 \times 3.84$

1.16 
Phellodon tomentosus (L. : Fr.) Baker is browncoloured (fawn, clay-buff, hazel, sienna etc.), with zonate upper surface, larger than the new species, and grows on open ground in gregarious or ring-shaped groups. The other related European species, Phellodon niger (Fr. : Fr.) P. Karst. and $P$. confluens (Pers.) Pouzar have a well-developed tomentum in their stipe, and their spores are larger than in P. secretus (Fig. 3, Tab. 1).

The species name of Hydnum occultum Britz. somehow points to the present species, but it was described to be 'fibrous, corky, woody', and having tints of yellow and brown; Maas Geesteranus (1960) suspected it to be an uncommon colour variety of $P$ hellodon connatus. Karsten identified his collection of the new species (Karsten 4677, listed above) as Hydnum cyathiforme Schaeff., which is considered to be a synonym of Phellodon tomentosus (Maas Geesteranus 1975): 'stipe rusty, aculei rosy; common' (Fries 1821). Original collection of Hydnum hepaticum Kalchbr. (UPS) was studied; the specimen is badly preserved, but it is much too robust to be our species, and Maas Geesteranus (in herb.) has measured the spores to be $4.5-4.9 \times 4.3 \mu \mathrm{m}$.

There are very many other, old, poorly understood names for stipitate hydnums, often missing authentic collections and identifiable by brief macroscopic descriptions and hand-made habit illustrations only. They were surveyed in particu-

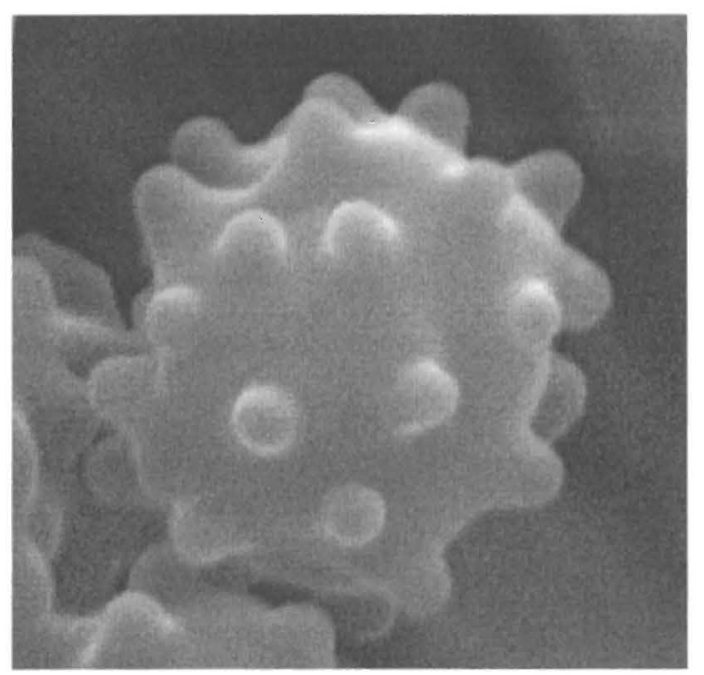

Fig. 4. Phellodon secretus Niemelä \& Kinnunen, spore ornamentation. SEM from holotype, $\times 15000$, prepared by DS. lar from Fries (1821) and Maas Geesteranus (1958, $1960,1964,1971,1975)$, but none of them seemed to match our new species. If this turns out to be a northern species, as it seems now, the probability of an older name is small.

Phellodon sinclairii (Berk.) G.H. Cunn., found in New Zealand, has larger spores than our species, 3.6-4.5 × 3.1-3.8 um (Maas Geesteranus 1971).

Hydnum pygmaeum Yasuda resembles our species in being small and having a dark stipe; the English translation of the description was published by Maas Geesteranus (1971: 31), who suspected this to be another synonym of $P$. connatum. The stipe was said to be 'brown to black' and the cap surface 'rather dark brown, with soft dense hairs', which does not fit well with P. secretus. We tried to get the type material on loan from TNS (Tokyo), but in vain.

Related species studied: Phellodon connatus: Finland. Varsinais-Suomi Prov.: Pohja, Dalkarby, 3.IX.1960 Såltin. Uusimaa Prov.: Espoo, Luukki, 20.VIII.1985 Koski-Kotiranta. Helsinki, Laajasalo, 28.IX.1934 Häyrén; Vuosaari, Kallvikudde, 2.IX.1993 Saarenoksa 29993. Tuusula, Klemetskog, Mätäkivenmäki, 21.IX.1944 Malmström. Satakunta Prov:: Tyrvää, 4.IX.1859 Karsten 2038. Etelä-Savo Prov.: Joutseno, Konnunsuo, Leppälä, 4.IX.1987 Kytövuori 871177. Kerimäki, Ruokojärvi, Louhi, 8.IX.1998 Kytövuori 981743. Pohjois-Savo Prov.: Savonranta, Muhamäki, 19.IX.1990 Haikonen 20367. Pohjois-Karjala Prov.: Eno, Uimaharju, 19.IX.1992 Kytövuori 922648. Liperi, Viinijärvi, Ahonkylä, 18.IX.1992 Kytövuori 922480. Oulun Pohjanmaa Prov.: Ylikiiminki, Karahka, 15.IX.1977 Ulvinen. Koillismaa Prov.: Kuusamo, Oulanka Nat. Park, 21.VIII.1992 Kytövuori 921484. Kittilän Lappi Prov.: Kolari, Äkäslompolo, Kesänki, 21.IX.2001 Kinnunen 1518. Sweden. Småland Prov.: Västra Ed, Västervik, 27.IX.1998 Kytövuori \& Kytövuori 982290. Germany. 'Hydnum melaleucum Fr., Germania, in silvis montosis abiegnis Thuringiae ad Saalfeldiam, Klotzsch Herb. Myc. n. 122, Septbr. Klotzsch et Opatowski' (Herb. E. Fries, UPS). Austria. 'Hydnum melaleucum, Österrike, Gabelberg prope Grein, 24.VIII.1866 Heufler' (Herb. E. Fries, UPS).

Phellodon niger: Finland. Uusimaa Prov.: Elimäki, Mustila, 1948 Schulmann. Espoo, Luukki, 3.IX.1993 Niemelä. Nurmijärvi, Parkkimäki, 25.IX.1988 Askola 2492; Pitkämäki, 10.IX.1977 
Askola 407; Kiljava, 22.IX.1985 Askola 1811. Tuusula, Nummenkylä, 9.IX.1943 Häyrén. EteläHäme Prov.: Lammi, Evo, Kotinen Virgin Forest, 14.IX.1979 Niemelä 1712; Alinen Rautjärvi, 4.IX.1981 Niemelä 2310.

Phellodon tomentosus: Finland. VarsinaisSuomi Prov.: Karjaa, NE of Kleven, Lövkullaudden, 25.IX.1990 Kytövuori 902033. Kemiö, Pedersâ, 21.IX.1990 Kytövuori 901839. Tammisaari, Bromarv, 17.IX.1992 Korhonen 11230.

Phellodon confluens: Sweden. Östergötland Prov.: Vadstena, 23.IX.1985 Kytövuori 851344. Gryt, 16.IX.1950 Nannfeldt 11181. U.S.A. Michigan: Washtenaw County, Waterloo, 10.X.1961 Hintikka.

Phellodon alboniger: U.S.A. Michigan: Wilderness State Park, 17.IX.1961 Hintikka.

Hydnum hepaticum: Hungary. 'Hydnum hepaticum nov. sp. Ungern: Scepusii, Oct. 1860 C. Kalchbrenner 173' (Herb. E. Fries, UPS).

Acknowledgements: Staff of the Natural Heritage Services, in particular Päivi Paalamo (Rovaniemi) and Maarit Similä (Lieksa) are thanked for inviting us to carry out mycological inventories in the Ylläs-Aakenus area and Koitajoki Nature Reserve, respectively, and for arranging us excellent working conditions. Yu-Cheng Dai, Olli Manninen, Kari Steffen and Olli Turunen accompanied us in fieldwork. Teuvo Ahti revised the Latin. Pertti Salo helped in finding the Karsten collections. Notes and improvements to the manuscript by Urmas Kõljalg are gratefully acknowledged. The author DS wishes to thank Drs. A. Davydovich, A. Bogdanov and N. Zvonkova (Laboratory of Electron Microscopy, Biology Faculty, Moscow State University) for help. Important specimens from the Fries herbarium (in UPS) were obtained on loan. Research grant from the Ministry of Environment (YM131/5512/2002) enabled us to carry out this study.

\section{References}

Ahti, T., Hämet-Ahti, L. \& Jalas, J. 1968: Vegetation zones and their sections in northwestern Europe. Ann. Bot. Fennici 5: 169-211.

Anonymous 1969: Flora of British fungi. Colour identification chart. - Royal Botanic Garden, Edinburgh. 6 unnumbered pp.

Baird, R.E. 1986a: Type studies of North American and other related taxa of stipitate hydnums, genera Bankera, Hydnellum, Phellodon, Sarcodon. - Biblioth. Mycol. 103: 1-89.

Baird, R.E. 1986b: Study of the stipitate hydnums from the Southern Appalachian Mountains, genera Bankera, Hydnellum, Phellodon, Sarcodon. - Biblioth. Mycol. 104: 1-156.
Breitenbach, J. \& Kränzlin, F. 1986: Fungi of Switzerland 2, non gilled fungi (Heterobasidiomycetes, Aphyllophorales, Gastromycetes). - Mykologia, Luzern. 412 pp.

Coker, W.C. \& Beers, A.H. 1951: The stipitate hydnums of the eastern United States. - Univ. North Carolina Press, Chapel Hill. 211 pp.

Domański, S. 1975: Mała flora grzybów 1, Basidiomycetes, Aphyllophorales 2. Auriscalpiaceae, Bankeraceae etc. - Państwowe Wydawnictwo Naukowe, Warszawa \& Kraków. 318 pp.

Fries, E.M. 1821: Systema mycologicum 1.- Berlingius, Lundae. 520 pp.

Hansen, L. \& Knudsen, H. (eds.) 1997: Nordic macromycetes 3, heterobasidioid, aphyllophoroid and gastromycetoid Basidiomycetes. - Nordsvamp, Copenhagen. $444 \mathrm{pp}$.

Holmgren, P.K., Holmgren N.H. \& Barnett, L.C. (eds.) 1990: Index herbariorum 1. The herbaria of the world. 8th ed. - New York Bot. Garden, Bronx. 693 pp.

Koivisto, A. (ed.) 2003: Ylläs-Aakenuksen alueen luonto. Nature in the Ylläs-Aakenus region. - Metsähallituksen Luonnonsuojelujulk. A 141: 1-213.

Kõljalg, U. \& Renvall, P. 2000: Hydnellum gracilipes, a link between stipitate and resupinate Hymenomycetes. - Karstenia 40: 71-77.

Maas Geesteranus, R.A. 1958: The stipitate hydnums of the Netherlands 3. Phellodon P. Karst. and Bankera Coker \& Beers ex Pouz. - Fungus 28: 48-61.

Maas Geesteranus, R.A. 1960: Notes on hydnums. Persoonia 1: 341-384.

Maas Geesteranus, R.A. 1964: Notes on hydnums 2. Persoonia 3: 155-192.

Maas Geesteranus, R.A. 1971: Hydnaceous fungi of the eastern Old World. - Verh. Koninkl. Nederlandse Akad. Wetensch. Afd. Natuurk. Tweede Reeks 60: 1-176.

Maas Geesteranus, R.A. 1975: Die terrestrichen Stachelpilze Europas. - Verh. Koninkl. Nederlandse Akad. Wetensch. Afd. Natuurk. Tweede Reeks 65: 1127, 40 tab.

Niemelä, T., Kinnunen, J. \& Dai, Y.C. 2003: Käävät (polypores). - Metsähallituksen Luonnonsuojelujulk. A 141: 81-107, 180-186.

Niemelä, T., Wallenius, T. \& Kotiranta, H. 2002: The kelo tree, a vanishing substrate of specified woodinhabiting fungi. - Polish Bot. J. 47: 91-101.

Nikolaeva, T.L. 1961: Flora sporovykh rasteniy SSSR 6, griby 2. Ezhovikovye griby. - Izdatel'stvo Akad. Nauk SSSR, Moskva \& Leningrad. 433 pp.

Petersen, J.H. (ed.) 1996: Farvekort. - Foreningen til Svampekundskabens Fremme, Greve. 6 unnumbered pp.

Rayner, R.W. 1970: A mycological colour chart. - CMI \& British Mycol. Society, Kew. 34 pp. +17 pls.

Stalpers, J.A. 1993: The aphyllophoraceous fungi 1. Keys to the species of the Thelephorales. - Stud. Mycol. 35: $1-168$. 